\title{
Theresienstadt Ghetto: Propaganda, Paintings, and Protest
}

\author{
Navya Agarwal ${ }^{1}$ and Kah Ying ${ }^{1 \#}$ \\ 1'Indus International School, Bangalore, India \\ \#Advisor
}

\section{$\underline{\text { ABSTRACT }}$}

Throughout history, art has been used to express, emote, and empathize. It has provided a lens to understand history beyond figures and statistics, through the eyes of the people. The aim of this research study was to conduct a case study analysis of an art movement that emerged from the Theresienstadt Ghetto as a protest movement against the endeavor by the Nazis to use the Jewish inmates and their work as a tool of propaganda during the Holocaust. This paper consists of two parts. First, a detailed discussion of the environment of Theresienstadt was presented to show its evolution from the Nazis' deceptive intent to put forth the illusion that it was a haven for Jewish people to the deterioration of living conditions and the audacious birth of an artistic hub upon the initiative of the Jewish inmates. Second, an in-depth analysis of four key works of art created in Theresienstadt, namely Transport Arrival by Leo Haas, a sketch by Helga Weissova, The Song is Over by Pavel Fantl, and Film and Reality by Bedrich Fritta, showcased the extraordinary courageous spirit of the artists in optimizing the meager resources they had to fight against their oppressors.

\section{Introduction}

Where there was not food for the body, there was food for the soul.

\section{- Historian Joza Karas, on Theresienstadt Ghetto}

The 1940s saw the greatest violation of human rights in the history of humankind. As a result of the Holocaust and World War II, 85 million people (around $3 \%$ of the world's population) died due to starvation, violence, or disease. ${ }^{1}$ But one aspect that history books often fail to address is the substantial losses in art, culture, and self-expression during this period. The volatile socio-political climate, combined with the harsh restrictions of Nazi Germany, made it virtually impossible for art to exist, especially in Europe. Thousands of creatives such as Jakob van Hoddis, Else Ury, Charlotte Salomon, and Georg John died at the hands of the Nazis, alongside their work. ${ }^{2}$

There is, however, one surprising place where art continued to survive, and in fact, flourished: Theresienstadt Ghetto. The arrival of the first lot of prisoners - a group of 342 Czech-Jewish men tasked with the preparation of Theresienstadt for thousands more Jews - on November 24th, 1941 marked its ill-fated beginnings. ${ }^{3}$ But little did they know, it would end up being celebrated as the birthplace of an underground art movement against Nazi Germany. ${ }^{4}$

\section{Methodology}

This research study involved a case study analysis of the Theresienstadt art movement. A case study analysis is ideal for this research study, as it involves the investigation of a phenomenon situated within a 'real-life' setting. ${ }^{5}$ Beyond providing a description of the phenomenon, it strives to forge a connection 'between a phenomenon and the context in which it is occurring. ${ }^{6}$ Hence, the analysis is divided into two parts: the context and the phenomenon. The 'context' 
refers to the political, socio-economic, and psychological factors from which the Theresienstadt art movement emerged. The 'phenomenon' — the protest art of Holocaust — is represented by four critical artworks created in Theresienstadt: Transport Arrival by Leo Haas, a sketch by Helga Weissova, The Song is Over by Pavel Fantl, and Film and Reality by Bedrich Fritta. These four pieces were selected after conducting a thorough review of Theresienstadt Ghetto art collections at Yad Vashem, Jewish Museum Berlin, and the United States Holocaust Memorial Museum. Ultimately, this selection strives to represent a diversity of interpretations of the same circumstance over time. A special emphasis is placed on the use of symbolism and stylistic choices to indicate how they reflected the author's condition and availability of resources in Theresienstadt. By situating these representative pieces within the context of the Theresienstadt, this research study provided a powerful lens for capturing the origination of these pieces as quintessence of protest art in the most soul-crushing of conditions - the Holocaust.

\section{Theresienstadt Ghetto: Origins and Conditions}

Theresienstadt (or Terezín in Czech) was originally a military fortress built by Emperor Joseph II of Austria in 1780 to protect Prague from Prussian troops during the periods of Austria-Prussia rivalry. ${ }^{7}$ Subsequently, it became a part of the newly-formed state of Czechoslovakia with the collapse of the Austro-Hungarian empire in 1918. During this period, it briefly served as a holiday resort for the Czech nobility. ${ }^{8}$ However, with the German invasion of Czechoslovakia and swift eviction of civilians in 1940, Theresienstadt would be unveiled to the world as a Nazi ghetto and 'transit camp' for Jews. ${ }^{9}$ The Jews sent to Theresienstadt were to later be deported to extermination, concentration, and forced-labor camps in Eastern German territories, such as Poland and Belarus. ${ }^{10}$

While all Nazi ghettos were unique, Theresienstadt was even more so. As a hybrid camp-ghetto, Theresienstadt was a holding pen for those considered unfit for forced labor. Inmates included elderly Jews, decorated and disabled war veterans, celebrities in the arts and culture, and Jewish prominenten: individuals with significant political connections. ${ }^{11}$ Among the celebrities and prominenten were intelligentsia, i.e., individuals educated in the arts or academics. Since the majority of this demographic was ineligible for forced labor, the Nazis sought to use Theresienstadt to camouflage its forced deportations. ${ }^{12}$

Branded as a 'privileged camp,' Theresienstadt was, in the words of Hitler, 'a city for the Jews,' to 'protect them from the ongoing war.' ${ }^{13}$ It was, quite cynically, marketed as a 'spa town' where the elderly Jews could 'spend their later years in peace.' 14 The Nazi incentive behind Theresienstadt was best summarized by Czech artist and inmate Norbert Troller:

Not only did they (the Nazis) expend great efforts to conceal the "Final Solution," but they attempted to create a colossal hoax: that rather than being tortured and killed, the Jews were actually well-treated guests of the Third Reich. ${ }^{15}$

Initially, Jews, especially the elderly, were quite smitten by this 'paradise ghetto'. ${ }^{16}$ Many signed fraudulent Heimeinkaufsvertrags (home purchase agreements) that essentially forced them to hand over all their assets. Others surrendered their insurance and paid 'deposits' for rent and resources in exchange for the perceived safety of Theresienstadt. ${ }^{17}$ The Nazis worked hard to provide an illusion of luxury and autonomy by asking inmates to 'specify in advance where they wanted their rooms, such as on the lake, by the square, etc. ${ }^{18}$

This illusion was amplified by the existence of a so-called Jewish self-administration known as the 'Council of Elders'. ${ }^{19}$ With these elders consistently promoting the idea that they had the power to maintain the lives of Theresienstadt's Jews, they inadvertently affirmed the Nazi deception that Theresienstadt was 'an autonomous, democratic, self-governing Jewish settlement.' ${ }^{20}$ In reality, the Council of Elders was simply an instrument of Nazi propaganda, which was not impervious to the corruptive influence of surviving under the Nazi rule. Council members responsible for distributing food often kept a majority for themselves, thus causing starvation among the common residents of Theresienstadt. ${ }^{21}$ Certain Elders were beating and deporting inmates on their accord, showing themselves to be far worse than the Nazi oppressors. Those who opposed deportations or failed to comply with Nazi standards were swiftly 
replaced by members chosen by the SS (the Schutzstaffel or Nazi Political Soldiers). Therefore, an Elder was 'powerless against even the lowliest SS man.' 22

It wasn't long before Theresienstadt followed the patterns of most 'inferior' ghettos, characterized by starvation, overcrowding and disease. The residents, given only a meager diet of limited cabbage and potatoes, were pushed to the brink of starvation. ${ }^{23}$ At its peak, Theresienstadt housed over 50,000 inmates in living quarters designed for 7,000. ${ }^{24}$ Triple-tiered bunks were crammed in every corner, bathrooms were scarce, and the entire landscape was covered with rats, lice, and flies. ${ }^{25}$ As Norbert Troller, an inmate at Theresienstadt, reported, '[O]ur calves were bitten and full of fleas that we could only remove with kerosene... ${ }^{26}$ The lack of adequate healthcare and overcrowding meant that inmates often fell prey to disease and pandemics. ${ }^{27}$ More than $30 \%$ of the ghetto's population became sick with scarlet fever, typhoid, or polio, among other diseases. ${ }^{28}$ The death toll within Theresienstadt reached $33,000 .{ }^{29}$

\section{Theresienstadt's Art: From Propaganda to Protest}

Conditions in the camp were harsh. Potatoes were as valuable as diamonds. I was hungry, scared, and sick most of the time. For my eighth birthday, my parents gave me a tiny potato cake with a hint of sugar; for my ninth birthday, an outfit sewn from rags for my doll; and for my tenth birthday, a poem written by my mother. ${ }^{30}$

This quote from Inge Auerbacher, who spent her childhood years at Theresienstadt, encapsulates perfectly the dire reality in the camp. More than just a chronicle of the conditions, it also points to how the inmates managed to cope with their conditions. When there is nothing else left, she could still count on 'a poem written by [her] mother.' And herein lies the 'magic' of Theresienstadt. In spite of this harsh reality, and possibly because of it, Theresienstadt evolved into a cultural and artistic Mecca. Its significant demographic of intelligentsia —artists, writers, musicians, playwrights, teachers, and cultural figures — found life through art and expression. ${ }^{31}$ All housed within a single camp, they worked together to create a climate to express their creativity and explore different ways it could be manifested in Theresienstadt. ${ }^{32}$

One could say that artistic expression offered an alternative source of 'nourishment' in the midst of severe deprivation in all the basic human needs. Through art, the people of Theresienstadt had an emotional outlet, a source of hope and a means of fostering community. It gave them a form of control, alleviated their fear and brought them closer together. ${ }^{33}$

The inmates' determined attempt to foster creativity at Theresienstadt became a way for them to defy their abject conditions and circumvent the Nazis' rules. For instance, even though the Nazis forbade education, the intelligentsia worked to ensure that the children received adequate education in the arts and languages. The people of Theresienstadt even found a loophole for the older children (who would otherwise be required to do grueling physical tasks) to get out of physical labor, by stating that they were engaged in performance work. ${ }^{34}$ Thus, many children were trained to sing, act, and dance. Every evening was filled with skits, lessons, and performances. Brundibár, a children's opera, was performed over 55 times. Students of the art teacher Friedl Dicker-Brandeis produced over 4,000 drawings. ${ }^{35}$ Their prolificity is a reflection of the sheer extent to which art enabled Theresienstadt's inmates to momentarily transcend their hellish circumstances. As Norbert Frýd, a Czech writer, so eloquently put it:

If Terezín was not hell itself, like Auschwitz, it was the anteroom to hell. ... Culture was still possible, and for many, this frenetic clinging to an almost hypertrophy of culture was the final assurance. We are human beings and we remain human beings... despite everything. ${ }^{36}$

The Nazis' stance on the proliferation of artistic activities at Theresienstadt was fraught with ambivalence. The truth was that the Nazis had been exploiting the talents of Theresienstadt for propaganda and manipulation. They relied on the facade of cultural activities and performances to conceal the harsh reality of starvation, disease, and violence. Prominent visual artists such as Bedrich Fritta and Norbert Toller were employed by the Technical 
Department to create propaganda artwork for the Nazis. This work included the production of romanticized depictions of Theresienstadt and administrative maps. ${ }^{37}$

However, the art would turn out to be a double-edged sword for the Nazis. Artists of the Technical Department used the supplies they were given to secretly create scenes that depicted the disease-ridden, miserable reality of the ghetto. Although most artists buried their work or hid it behind walls, some smuggled out their art through inmates that had jobs outside Theresienstadt. ${ }^{38}$

One such artist was Leo Haas. After getting arrested by the Nazis for allegedly joining a Communist party, he was transported to Theresienstadt to work in the Technical Department. In his words:

At Terezin, in order to protect my friends and me from being sent to the gas chambers at Auschwitz, the self-administration put us to work on construction management, where we did architectural drawings - partly for real, but largely as a means of camouflage. ${ }^{39}$

However, much like his fellow artists, Haas did not adhere solely to his 'official' task. Instead, he sought to make use of the resources at his disposal to depict the realities of the camp.

It was clear that we should not only use the material that was put at our disposal for that purpose, so we marched around drawing whatever we regarded as notable... I did it because it was what I felt I should do,... in all camps... create witness testimony... and to some extent create evidence. ${ }^{40}$

A perfect example of one such piece is Transport Arrival (see Fig. 1). At first glance, Transport Arrival may have looked like hundreds of other propaganda landscapes that Haas was forced to create.

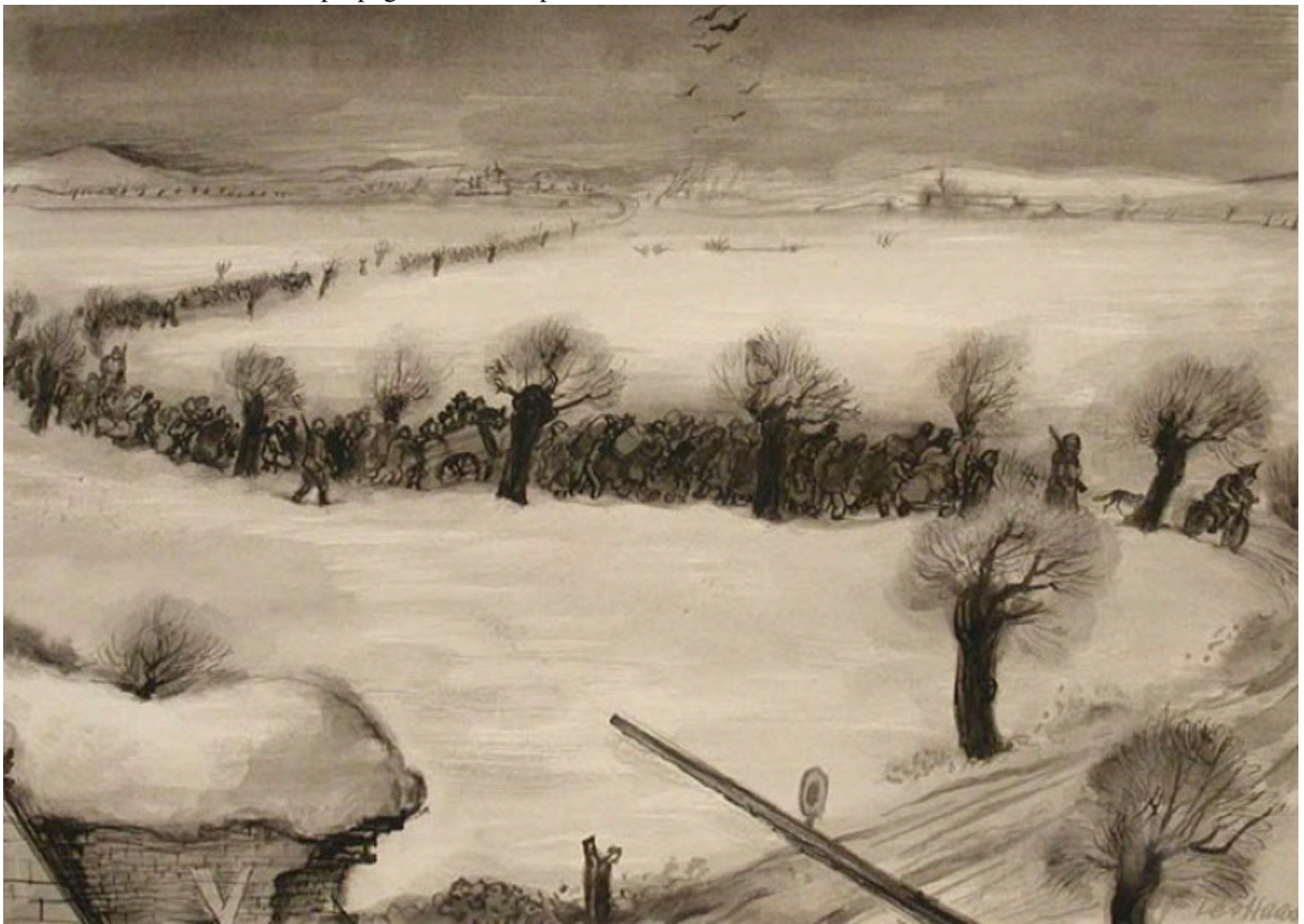

Fig. 1 Leo Haas, Transport Arrival, 1942. Indian ink on paper, 37.7 x $49.2 \mathrm{~cm}$. Jerusalem: Collection of the Yad Vashem Art Museum. Photo: Yad Vashem Art Museum.

However, a closer look would reveal the throngs of hunched silhouettes of the new inmates walking alongside the lifeless trees, flanked by armed soldiers escorting them, which brilliantly capture the bleakness of the realities of 
Theresienstadt. With its dark tones, birds of prey, and baleful trees, it is not hard to see how the sketch constitutes a perfect allegory of death, which hardly matches the SS's desire to prevent the reality of Theresienstadt from ever being depicted.

But that was not all. Haas took it one step further by sketching a letter, ' $\mathrm{V}$ ', at the bottom right corner of the painting. Some had suggested that it was an unmistakable reference to British Prime Minister Winston Churchill's popularization of the 'V for victory' - a rallying emblem against Germany and the Allied powers' symbol for Nazi resistance. ${ }^{41}$ Others had proposed the possibility of ' $\mathrm{V}$ ' as a symbol of Theresienstadt's very own underground movement. ${ }^{42}$ However, it has been pointed out that the ' $\mathrm{V}$ ' also has a special place in Germany's rallying movement, as it stands for 'Viktoria, the Roman goddess of victory. ${ }^{\text {'3 }}$ While one could dismiss the relevance of Haas' use of 'V' as a meaningful symbol of protest due to the absence of a definite meaning, I would argue that the ambivalence of its true meaning provided the ultimate camouflage for Haas' protest.

The risk that Haas took cannot be under-estimated. Just two years after the creation of Transport Arrival, in 1944, Haas was accused of 'smuggling atrocity propaganda abroad,' which led to his deportation to Auschwitz. ${ }^{44}$ He was one of the few Auschwitz inmates who made it out alive. After liberation, over 500 of Haas' drawings were used as court evidence for Nazi atrocities and provided justice for thousands of Holocaust victims. ${ }^{45}$

However, it is important to point out that at the time, few artists were willing to take the same risks as Leo Haas and his associates. Only a small quantity of what the SS called 'degenerate art' were created and resistance movements were still unpopular initially. The SS did not perceive any danger from the existing cultural activities, and throughout 1942, they adopted a permissive attitude about artistic activities in Theresienstadt such as the children's art lessons. This was based on the assumption (at the time) that it was highly unlikely for any art to leave the ghetto. ${ }^{46}$ Hence, young inmates, such as Helga Weissova continued to benefit from the over 100 art classes conducted by the Theresienstadt intelligentsia. ${ }^{47}$ Little did the SS know, these classes would one day give Helga the skills to produce a historical sketch that would contradict the SS' 'beautification' campaign to hide the conditions at Theresienstadt from the Danish Red Cross in 1944.

In October 1943, 476 Danish Jews were deported to Theresienstadt. ${ }^{48}$ By November 1943, The Danish authorities had grown increasingly concerned about the conditions of the Danish Jews upon reading a report by the DRK (German Red Cross) that described the ghetto as 'dreadful' and 'frightfully overcrowded.' ${ }^{9}$ By early 1944, the Danish Government, the Danish Red Cross, and International Red Cross started pressuring the Nazis to authorize an inspection of Theresienstadt. Determined to counteract previous findings by the DRK, the SS promised that Danish representatives would be allowed to visit Theresienstadt in June $1944 .^{50}$

The next few months (February to June) were then dedicated to converting Theresienstadt into the "model ghetto' as advertised. ${ }^{51}$ The 'Verschönerung' or 'beautification' program, as it was called, involved the relocation, rehabilitation, and reconstruction of Theresienstadt. Over 7,000 elderly, sick, and disabled citizens of Theresienstadt were deported to Auschwitz because they had no place in the 'ideal Jewish settlement.' 52 Danish Jews and prominteen were housed in larger, 'superior' quarters to appease the Danish Government. The remaining inmates were fed and nursed like never before. Curfews were postponed and compulsory salutations were eradicated. Inmates swept the streets, painted buildings, and planted roses. ${ }^{53}$ The SS exploited the artistic talents of Theresienstadt's inmates to create an illusion of a social and cultural life, one that would appear to represent 'freedom' to the outside visitors. The SS planned to host a football match and put up Brundibaár - a special performance for the inspectors. A 'Potemkin Village' of shops, playgrounds, cafés, nurseries, schools, and bandstands was constructed within months. ${ }^{54}$ Colorful umbrellas, jewelry, and clothes were on 'sale' to showcase the prevalence of the arts, although many of the possessions displayed were actually taken from the inmates. ${ }^{55}$ Decorative signs, gardens, and benches appeared. Even the interior of certain dorms, especially those on the lower floors, were altered. ${ }^{56}$

Documenting the SS' campaign to deceive the visitors, Helga produced a sketch that showed men sawing off a top layer of a bunk bed in order to eradicate the look of overcrowding (see Fig. 2) ${ }^{57}$ Even though the residents of Theresienstadt typically slept in three-layer bunks to maximize space, all top bunks were removed and shifted to underground basements before the visit. Helga honored the words of her father, Ottis Weiss, who had told her to 
'draw what you see,' and she did just that every day. ${ }^{58}$ In a place where 'the perversion of truth became the normal way of conducting business,' her chronicling of this behind-the-scenes program served to preserve the truth for posterity. ${ }^{59} \mathrm{Had}$ any of the Red Cross inspectors seen Helga's sketch, the elaborate hoax of Theresienstadt would have been unraveled. Unfortunately, Helga's sketch would only be revealed to the world many years later.

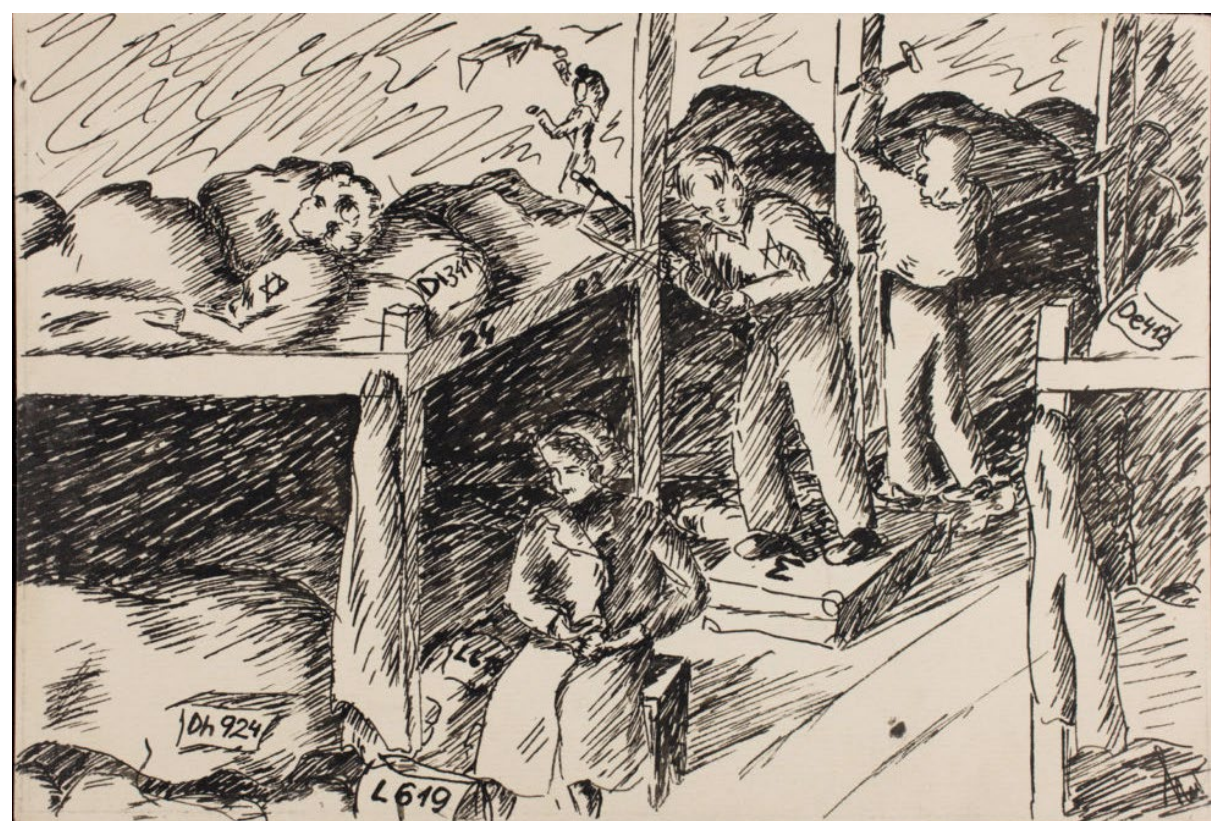

Fig. 2 Helga Weissova, Untitled, 1944, in Ruth Thomson, Terezin: A Story of the Holocaust, London, $2011,48$. Franklin Watts, Hachette UK Ltd.

Sadly, despite their efforts to capture the truth, the artists could not smuggle out their artwork in time to change the outside impressions of Theresienstadt. On June $23^{\text {rd }}, 1944$, the day of the Red Cross visit, visitors were led through a predetermined path, where they interacted with 'residents' who were trained to make statements about the 'delicious food' and the 'prevalence of culture' at Theresienstadt. ${ }^{60}$ The final Red Cross report made statements such as 'the SS police gives the Jews the freedom to organize their administration as they see fit' and 'The Terezín camp is a final camp, from which no one who has once entered the ghetto is normally sent elsewhere. ${ }^{61}$ An anecdote by Charlotte Guthmann Offermann, a child imprisoned in Theresienstadt, addressed a report by one of the visitors:

In June 1944, Maurice Rossel, then working for the Geneva office of the International Red Cross, wrote a glowing report after a brief visit to the camp. The Red Cross archives did not release this report... until 1992, almost fifty years later. I am one of the children captured in several of his photographs... All of the seemingly happy children and their caregivers whom Rossel photographed in June were dead within weeks after his visit. $^{62}$

What the likes of artists like Helga had done during that time was to contribute to the groundswell of the underground resistance movements of Leo Haas and his associates. As artists living in Theresienstadt became more exposed to the deception of the SS, they felt more and more emboldened to use their work to express reality. As their artistic expression became bold and reckless, 'degenerate art' was created throughout the ghetto. ${ }^{63}$

While many artists created artwork with the intent of sharing and exposing the true conditions of Theresienstadt, the power of art also lay in its cathartic purpose. One example of an artist who used his art to do both - explicitly attack the Nazi regime and release repressed feelings, is Pavel Fantl. In Pavel's most famous piece, The Song is Over, 
he portrayed Adolf Hitler as a bloody, drunken street clown, surrounded by bottles of booze, a broken string instrument, and a black animal (see Fig. 3).

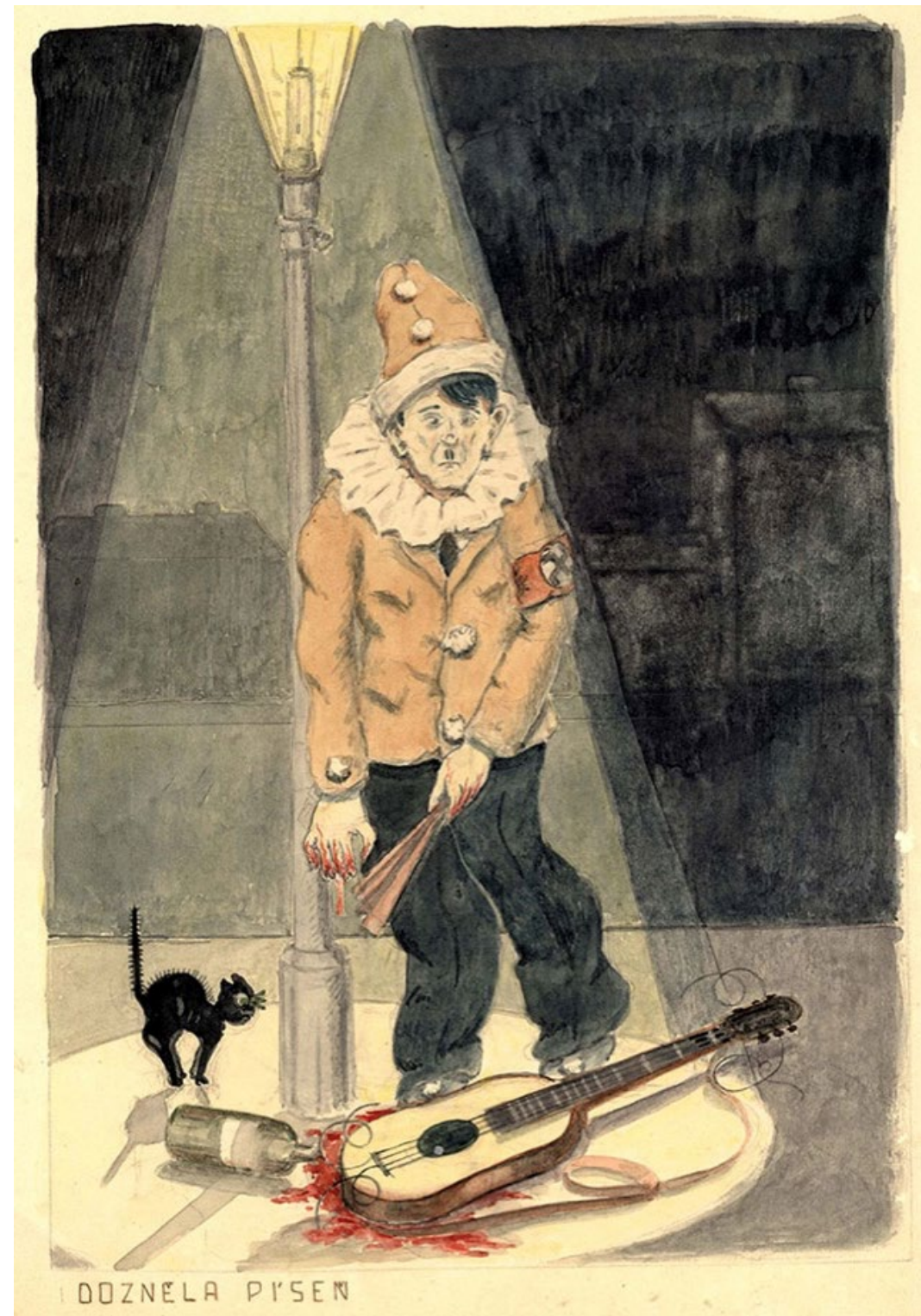

Fig. 3 Pavel Fantl, The Song is Over, 1944. Watercolor and Indian ink on paper, 30.2 x $22.5 \mathrm{~cm}$. Jerusalem: Collection of the Yad Vashem Art Museum.@ Ida Fantlová. Photo: Yad Vashem Art Museum.

This sketch is a blatant mockery of the Nazi regime and its leader. As Walter Smerling, a collection curator, remarked on this art piece, '[Pavel] portrays Hitler as a clown, and the instrument on which he [Hitler] played the melodies with which he deceived an entire people, is on the floor, destroyed, with blood on his hands. ${ }^{64}$ The Song is Over also has an element of irony: people during the Holocaust were forced to keep a portrait of Hitler up as a symbol of respect. As a travesty of the formal version, this portrait of Hitler, with its satirical dimension, is a barely-concealed symbol of resistance and opposition.

Pavel's desire to express the truth on paper was so strong that he risked his life in order to do so. He smuggled out over 80 versions of such works, before the Nazis noticed and sent him to Auschwitz, where he died. ${ }^{65}$ Nevertheless, his artwork lives on today as a symbol of strength, freedom, and resistance. Currently, The Song is Over, along with 
many other pieces by Pavel, is on display at the Yad Vashem Art Museum in Jerusalem, as a reminder of past atrocities and a testament to those who dared to stand up.

Another such protest artist was Bedrich Fritta, a cartoonist who created hundreds of artworks depicting 'true ghetto life,' especially during the 'beautification' period. ${ }^{66}$ One of his most creative pieces, Film and Reality, is a satirical reference to the propaganda documentary created by the SS in the wake of the Red Cross visit (see Fig. 4). The documentary, entitled Der Führer schenkt den Juden eine Stadt ('The Leader Gives the Jews a Town as a Gift') was designed to highlight the beautified parts of the ghetto and depict Theresienstadt in a positive light. ${ }^{67}$ Kurt Gerron, a renowned Jewish film director, was forced to create it with the help of hundreds of prisoners who were immediately deported to Auschwitz after the film's completion. ${ }^{68}$ The film was completed in early 1945 , but it was never fully released due to the ending of World War II. Bedrich Fritta watched the entire process of the film's creation, which gave him the insights required to create Film and Reality. ${ }^{69}$

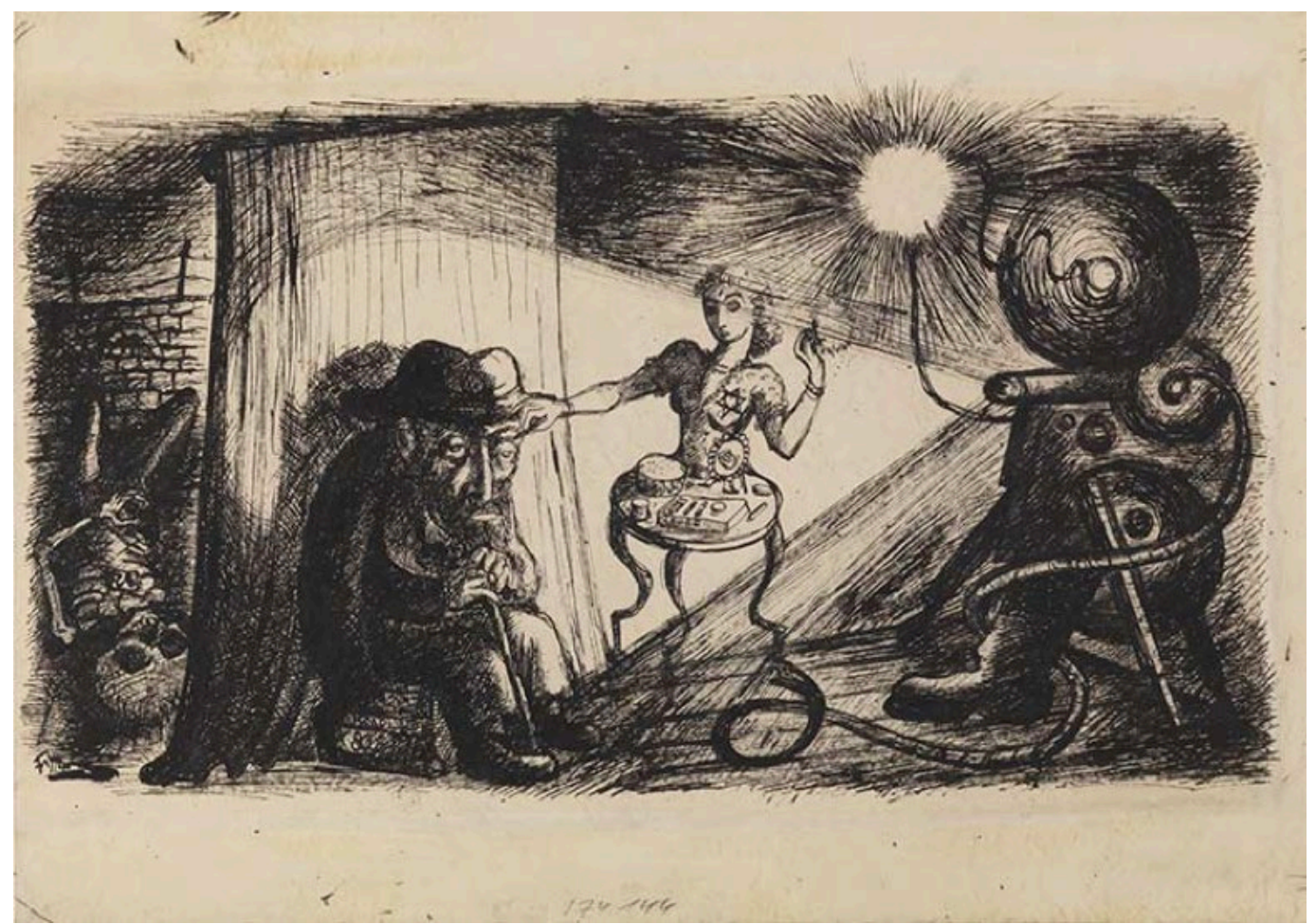

Fig. 4 Bedrich Fritta, Film and Reality, 1944. Pen and ink on paper, 31.1 x $56.1 \mathrm{~cm}$. Berlin: Jewish Museum Berlin. (C) Thomas Fritta-Haas. Photo: Jens Ziehe

This ink sketch depicts an elderly man sitting in front of a movie theatre curtain that hides a skeleton. The curtain draws a metaphorical line between film and reality. While the 'film' part of the title refers to the elaborate showcase being projected, which is symbolic of the façade that SS showed to the rest of the world, the hidden 'reality' is the concealed 'skeleton(s) of the closet' of Theresienstadt, which were packed away. The man sitting in front of the curtain appears oblivious, indicating how many people turned a blind eye to the SS manipulation and deception. The movie reel is almost shaped like a dictator, possibly symbolizing Hitler controlling the filming process. Although the entire piece was created with a single color, Fritta's use of highlights and shadows enabled him to show how the spotlight was focused on the SS propaganda or 'film,' while the 'reality' was wholly obscured in plain sight. As with the other valiant artists, some artworks that Bedrich smuggled out were discovered by the Nazis in July of 1944 . He and his family were deported to Auschwitz, where he later died of exhaustion. ${ }^{70}$ 
Nevertheless, these artists did not die in vain. Ultimately, justice prevailed as the Soviet troops liberated Theresienstadt on May 8th, 1945. By this time, only 19,000 of the 144,000 Jews who had once lived in Theresienstadt were alive. ${ }^{71}$ However, the legacy of thousands of Jews continues to survive in the artwork left behind by the inmates of Theresienstadt. Today, the artwork and artifacts from Theresienstadt are widely exhibited as reminders of Theresienstadt's artists' courage to maintain their humanity and dignity in the face of efforts to degrade them. ${ }^{72}$ You can see them at a special focus exhibition in the United States Holocaust Memorial Museum. ${ }^{73}$ Visitors to the Jüdisches Museum in Berlin can gain insights into the day-to-day life at Theresienstadt through drawings that serve to illuminate the past atrocities that humanity has suffered and underscore the statement, 'Never again.' 74

\section{Conclusion}

What this study of Theresienstadt has hopefully shown is the power of art in empowering people to fight back at individual and collective levels. At an individual level, art was a discipline that instilled the desire for survival in the inmates:

Today only one thing seems important - to rouse the desire towards creative work, to make it a habit, and to teach how to overcome difficulties that are insignificant in comparison with the goal to which you are striving. ${ }^{75}$

With his words, Friedl Dicker-Brandeis (an artist and inmate at Theresienstadt) highlighted how the 'habit' of creating art could enable individuals to transcend the most terrible circumstances. This perseverance to pursue a creative process, undaunted by the surrounding situation, is, in and of itself, a defiant act of protest. Highlighting the inherent human need to create and express, the art of Theresienstadt has shown that, even in a universe where people lack food, hygiene, and healthcare, they will survive with art. Hopefully, this account has inspired readers to reflect on the nature of expression and creativity in their own lives.

At a collective level, the existence of Theresienstadt shows how art can unite the oppressed and empower them to build a sense of community in places intended to tear people apart and crush their spirit. To realize their united purpose of protesting against the Nazis' mission of using them as a propaganda tool, the inmates of Theresienstadt had to work together to educate their children and divert the sources to create an authentic representation of the camp and smuggle the artworks out. Most of all, they had to be willing to sacrifice their own lives and those of their families.

As true artists, the inmates of Theresienstadt were in pursuit of the truth, which they captured in the protest art they were making. Being subjected to the horrors of the camps and exposed to the lies that the SS were showing to the world, they could not, in good conscience, allow the SS's deceitful portrayals to be the sole representation of what was happening to them as a community and as a people. In this instance, art and socio-political realities became inextricably interwoven together, with art serving as a vital fighting tool to thrust the ugly darkness of the Holocaust into the light.

This case study of Theresienstadt provided an atypical lens for examining the oft-studied topic of the Holocaust. Instead of using statistics to illuminate the horrors of this dark episode of human history, this case study analysis of the extraordinary Theresienstadt Ghetto showed how art was harnessed as a tool of protest to fight back against injustice and inhumanity on a massive, incomprehensible scale. The existence of these art pieces not only serves to chronicle the Holocaust, but also inspires us with the indomitability of the human spirit that refuses to give up. While the SS sought to wrest away every ounce of control from the inmates of Theresienstadt by destroying their lives and then cover up the actuality with a deceitful version, the artists refused to be silenced and fought back with their art.

With that being said, it is important to acknowledge that due to the highly interpretative nature of art as a historiographical source, it is easy for the artists' intended meaning to get lost in interpretation. Furthermore, the 
context (Theresienstadt Ghetto) may not be universally experienced by all creators of the phenomenon (the artists). All four artists occupied different parts of the ghetto at different time periods, and hence, may have varied interpretations of their circumstance. Additionally, it must be noted that the art analyzed in this study is merely a fraction of the art that was created during the Holocaust as a whole. The artists in question represent a privileged strata of the oppressed - most victims of the Holocaust had neither the opportunity nor resources to exercise creative expression.

Nevertheless, in this day and age, as the oppression of minority groups persists, the use of art as a means of examining the lived realities of coping with the situation on the ground would offer unique insights, which cannot be easily replicated with other approaches. This same art-based approach can be easily applied to any other historical conflict and yield profoundly different insights. It thus holds the potential to further expand our appreciation of art, who we are as individuals and as a community. In a deeper sense, it can even help us to understand what it truly means to be human.

\section{Acknowledgements}

I would like to thank my advisor Kah Ying Choo for helping me with this project. Additionally, I am grateful to the United States Holocaust Memorial Museum, Yad Vashem, and the Jewish Berlin Museum for comitting to the retrieval and dissemination of art from Theresienstadt Ghetto.

\section{Endnotes}

1. Lipstadt, Deborah, Denying the Holocaust:The growing assault on truth and memory, New York, 2012.

2. Kay Weniger, Das Große Personenlexikon des Films [The Film’s Great Encyclopedia of People], Berlin, 2001.

3. Norbert Troller, Theresienstadt: Hitler's Gift to the Jews, Chapel Hill, 2004.

4. Livia Rothkirchen, The Jews of Bohemia and Moravia: Facing the Holocaust, Lincoln, 2005.

5. Robert K. Yin, Case Study Research: Design and Methods, Los Angeles, 2009.

6. David E. Gray, Doing Research in the Real World, London, 2014.

7. Mirko Truma, 'Memories of Theresienstadt', Performing Arts Journal 1:2, 1976, 12-18.

8. Dragan Damjanović, 'The Hatzinger Family of Builders - from Székesfehérvár, through Osijek, Lviv, and Zadar to Vienna', Acta Historiae Artium, 57:1, December 2016, 167-186.

9. Troller, Theresienstadt: Hitler's Gift.

10. Troller, Theresienstadt: Hitler's Gift.

11. Troller, Theresienstadt: Hitler's Gift.

12. United States Holocaust Memorial Museum, Theresienstadt: Red Cross Visit.

13. Timothy Sprehe,'Defiant Requiem: Verdi at Terezin', Society 44: 1, 2006, 89-93. 
14. Hannelore Brenner-Wonschick, The Girls of Room 28 : Friendship, Hope, and Survival in Theresienstadt, New York, 2009.

15. Troller, Theresienstadt: Hitler's Gift.

16. Aime Bonifas, “A "Paradisiacal” Ghetto of Theresienstadt: The Impossible Mission of the International Committee of the Red Cross', Journal of Church and State 34: 4, 1992, 805-818.

17. Brenner-Wonschick, The Girls.

18. George E. Berkley, Hitler's Gift : The Story of Theresienstadt, Boston, 1993.

19. Bonifas, 'A "Paradisiacal" Ghetto of Theresienstadt'.

20. Brenner-Wonschick, The Girls.

21. H. G. Adler, Theresienstadt, 1941-1945 the Face of a Coerced Community, New York, 2017.

22. Adler, Theresienstadt.

23. Barbara L. Brush, 'Caring for Life: Nursing during the Holocaust', Nursing History Review 10:1, 2002, 69-81.

24. Esther V. Levy, Legacies, Lies and Lullabies : The World of a Second Generation Holocaust Survivor, Sarasota, 2013.

25. Levy, Legacies.

26. Troller, Theresienstadt: Hitler's Gift.

27. Levy, Legacies.

28. Brush, 'Caring for Life'.

29. Otto Kulka and Ruth Bondi, 'Theresienstadt', Encyclopaedia Judaïca 15, 1990, 1112-1117.

30. Hallie Murray and Ann Byers, Life in the Nazi Ghettos, New York, 2019.

31. Troller, Theresienstadt: Hitler's Gift.

32. Rothkirchen, The Jews.

33. Rebecca Rovit and Alvin Goldfarb, Theatrical Performance during the Holocaust: Texts, Documents, Memoirs, Baltimore, 1999.

34. Gonda Redlich and Saul S. Friedman, The Terezin Diary of Gonda Redlich, Lexington, 1992. 
35. Levy, Legacies.

36. Nancy Goodman and Marilyn Meyers, The Power of Witnessing : Reflections, Reverberations, and Traces of the Holocaust, New York, 2012.

37. Troller, Theresienstadt: Hitler's Gift.

38. Levy, Legacies.

39. Marc Wrasse, "Deutsches Historisches Museum: Artists \& Works," in Deutsches Historisches Museum, n. d., https://www.dhm.de/en/ausstellungen/archive/2016/art-from-the-holocaust/artists-works.html.

40. Ibid.

41. Victor de Laveleye, 'Radio Belgique', BBC European Service, January 1941.

42. Mary Lane, 'Art From the Holocaust; The Beauty and Brutality in Forbidden Works', The New York Times, January 2016.

43. Victor de Laveleye, "Radio Belgique".

44. United States Holocaust Memorial Museum, Days of Remembrance, April 3-10, 1994: Planning Guide for Commemorative Programs, Washington, DC, 1994.

45. Ibid.

46. Ludmila Chládková, The Terezín Ghetto, Praha, 2005.

47. Patricia Heberer, Children during the Holocaust, Lanham, 2011.

48. Meir Dworzecki, "The International Red Cross and Its Policy Vis-a-vis the Jews in Ghettos and Concentration Camps in Nazi-Occupied Europe" in The Nazi Holocaust. Part 8: Bystanders to the Holocaust, ed. Michael Robert Marrus, vol. 2 (Meckler, De Gruyter Saur, 1989), 1159.

49. Rothkirchen, The Jews.

50. Rothkirchen, The Jews.

51. Levy, Legacies.

52. Rothkirchen, The Jews.

53. Rothkirchen, The Jews.

54. Jack Fischel and Mazal Holocaust Collection, The Holocaust, Westport, 1998. 
55. Elisabeth Maxwell and John K Roth, Remembering for the Future : The Holocaust in an Age of Genocide, New York, 2001.

56. Levy, Legacies.

57. Adler, Theresienstadt: The Face.

58. Adler, Theresienstadt: The Face.

59. Troller, Theresienstadt: Hitler's Gift.

60. Maxwell and Roth, Remembering.

61. Maurice Rossel, 'Excerpt from the Report by Maurice Rossel from the ICRC on His Visit to Terezín in 1944,' Jewish Museum in Prague, Terezín, 1944.

62. Charlotte Opfermann, "Beware of Answered Prayers: Ghetto-Concentration Camp Theresienstadt/Terezin", in Life in the Ghettos During the Holocaust, ed. Eric Sterling (Syracuse,: Syracuse University Press, 2005), $28-29$.

63. Kurt Wallach, Man’s Inhumanity To Man, Morrisville, 2020.

64. Thomas Rogers, "Art from the Holocaust: The Stories behind the Images,” BBC, n. d., https://www.bbc.com/culture/article/20160203-art-from-the-holocaust-the-stories-behind-the-images.

65. Jörn Wendland, Das Lager von Bild Zu Bild: Narrative Bildserien von Häftlingen Aus NS-Zwangslagern, Köln, 2017.

66. Levy, Legacies.

67. Andrew Woolford, "The Führer Gives the Jews a Town: Impression Management, Homo Dramaticus, and Bare Life in Theresienstadt," Crime, Media, Culture: An International Journal 6, no. 1 (2010): 87-104, https://doi.org/10.1177/1741659010363043.

68. Ibid.

69. Irina Sandomirskaja, "Welcome to Panorama Theresienstadt. Cinematography and Destruction in the Town Called 'As If' (Reading H. G. Adler)," Apparatus Journal, no. 2-3 (2016), https://doi.org/http://dx.doi.org/10.17892/app.2016.0002-3.48.

70. Gerald Green, Artists of Terezin, New York, 1969.

71. Naomi Pasachoff, Great Jewish Thinkers: Their Lives and Work, West Orange, 1993.

72. United States Holocaust Memorial Museum, 2019, "Online Exhibition: Special Focus Theresienstadt," https://www.ushmm.org/information/exhibitions/online-exhibitions/special-focus/theresienstadt.

73. Ibid. 
74. "Bedřich Fritta: Drawings from the Theresienstadt Ghetto,” Jewish Museum Berlin, accessed June 22, 2020, https://www.jmberlin.de/en/exhibition-bedrich-fritta.

75. Julie Salamon, 'Keeping Creativity Alive, Even in Hell', The New York Times, September 2004.

\section{References}

Adler, H. G., Belinda Cooper, Amy Loewenhaar-Blauweiss, and Jeremy D Adler. Theresienstadt, 1941-1945: The Face of a Coerced Community. New York: Cambridge University Press, 2017.

"Bedřich Fritta: Drawings from the Theresienstadt Ghetto." Jewish Museum Berlin. Accessed June $22,2020$. https://www.jmberlin.de/en/exhibition-bedrich-fritta.

Berkley, George E. Hitler's Gift : The Story of Theresienstadt. Boston: Branden Books, 1993.

Brenner-Wonschick, Hannelore. The Girls of Room 28: Friendship, Hope, and Survival in Theresienstadt. New York: Schocken Books, 2009.

Brush, Barbara L. "Nursing Care and Context in Theresienstadt." Western Journal of Nursing Research 26, no. 8 (December 2004): 860-71. https://doi.org/10.1177/0193945904265333.

Burt, Kate. "The Art That Fought the Holocaust." Ha'am. February 20, 2020. https://haam.org/the-art-that-foughtthe-holocaust/.

Christian, Ingrao. "General Chronology Of Nazi Violence." Sciences Po France, 2008. https://www.sciencespo.fr/mass-violence-war-massacre-resistance/fr/document/general-chronology-naziviolence.html.

Damjanović, Dragan. “The Hatzinger Family of Builders - from Székesfehérvár, through Osijek, Lviv, and Zadar to Vienna." Acta Historiae Artium 57, no. 1 (2016): 167. https://doi.org/10.1556/170.2016.57.1.6.

de Laveleye, Victor. "Radio Belgique.” BBC European Service, January 14, 1941.

Dworzecki, Meir. "The International Red Cross and Its Policy Vis-a-vis the Jews in Ghettos and Concentration Camps in Nazi-Occupied Europe." Part 5 in The Nazi Holocaust. Part 8: Bystanders to the Holocaust. Edited by Michael Robert Marrus. vol. 2. Meckler, De Gruyter Saur, 1989.

Fischel, Jack, and Mazal Holocaust Collection. The Holocaust. Westport: Greenwood Press, 1998.

Goodman, Nancy, and Marilyn B. Meyers. The Power Of Witnessing. Hoboken: Taylor and Francis, 2012.

Gray, David E. Doing Research in the Real World. London: Sage, 2014.

Green, Gerald. Artists of Terezin. New York: Schocken. 
Heberer, Patricia. Children during the Holocaust. Lanham: Rowman \& Littlefield Publishers, 2011.

Hilberg, Raul. The Destruction of the European Jews. vol. 1. New York: Holmes \& Meier, 1985.

“Inge Auerbacher." United States Holocaust Memorial Museum Encyclopedia. Accessed February $20,2020$. https:/encyclopedia.ushmm.org/content/en/id-card/inge-auerbacher.

Jewish Virtual Library.org. "History \& Overview of Terezin.” 2018. https:/www.jewishvirtuallibrary.org/historyand-overview-of-terezin.

Karas, Joža. Music in Tereziín: 1941-1945. New York: Beaufort Books, 1985.

Kraft, Helga, and Dagmar C. G. Lorenz. From Fin-de-Siècle To Theresienstadt: The Works and Life of the Writer Elsa Porges-Bernstein. New York: P. Lang, 2007.

Lane, Mary. "Art From the Holocaust: The Beauty and Brutality in Forbidden Works." The New York Times, January 22, 2016. https://www.nytimes.com/2016/01/23/arts/design/art-from-the-holocaust-the-beauty-and-brutality-inforbidden-works.html.

Levy, Esther V. Legacies, Lies and Lullabies : The World of a Second Generation Holocaust Survivor. Sarasota: First Edition Design Publishing, 2013.

"Life In Shadows: Hidden Children And The Holocaust - Exhibition Script." United States Holocaust Memorial Museum. 2004. https://www.ushmm.org/exhibition/hidden-children/insideX/.

Ludmila Chládková. The Terezín Ghetto. Praha: Památnik Terezin, 2005.

Ludwig, Mark. "Silenced Voices: Music in the Third Reich." Religion and the Arts 4, no. 1 (March 1, 2000): 96-112. https://doi.org/10.1163/15685290152126449.

Margry, Karel. 1992. "Theresienstadt (1944-1945): The Nazi Propaganda Film Depicting the Concentration Camp As Paradise." Historical Journal Of Film, Radio And Television 12, no. 2: 145-162. doi:10.1080/01439689200260091.

Maxwell, Elisabeth, and John K. Roth. Remembering for the Future: The Holocaust in an Age of Genocide. New York: Palgrave, 2001.

Megargee, Geoffrey P., Martin Dean, Doris L. Bergen, and United States. The United States Holocaust Memorial Museum Encyclopedia of Camps and Ghettos, 1933-1945. Bloomington: Indianapolis Indiana University Press in Association with the United States Holocaust Memorial Museum, 2009.

Murray, Hallie, and Ann Byers. Life in the Nazi Ghettos. New York: Enslow Publishing, 2019.

Opfermann, Charlotte. "Beware of Answered Prayers: Ghetto-Concentration Camp Theresienstadt/Terezin.” Ch. 3 in Life in the Ghettos During the Holocaust. Edited by Eric Sterling. Syracuse: Syracuse University Press, 2005.

Pariser, David. "A Woman of Valor: Freidl Dicker-Brandeis, Art Teacher in Theresienstadt Concentration Camp." Art Education 61, no. 4 (2008): 6-12. www.jstor.org/stable/20694738. 
Pasachoff, Naomi. Great Jewish Thinkers: Their Lives and Work. West Orange: Behrman House C, 1993.

Patz, Naomi. "What You Need to Know about Terezín." Lexham Arts. April 27, 2009. http://www.lexhamarts.org/theater/200906/BackgroundInfo.htm.

Redlich, Gonda, and Saul S Friedman. The Terezin Diary of Gonda Redlich. Lexington: University Press Of Kentucky, 1992.

Rogers, Thomas. "Art from the Holocaust: The Stories behind the Images." BBC. n. d. https://www.bbc.com/culture/article/20160203-art-from-the-holocaust-the-stories-behind-the-images

Rossel, Maurice. "Excerpt from the Report by Maurice Rossel from the ICRC on His Visit to Terezín in 1944." Jewish Museum in Prague. 1944. http://collections.jewishmuseum.cz/index.php/Detail/Object/Show/object id/134242.

Rothkirchen, Livia. The Jews of Bohemia and Moravia: Facing the Holocaust. Lincoln: University of Nebraska Press, 2005.

Rovit, Rebecca, and Alvin Goldfarb. Theatrical Performance during the Holocaust: Texts, Documents, Memoirs. Baltimore: Johns Hopkins University Press, 1999.

Salamon, Julie. "Keeping Creativity Alive, Even in Hell." The New York Times, September 10, 2004. https://www.nytimes.com/2004/09/10/arts/design/keeping-creativity-alive-even-in-hell.html.

Sandomirskaja, Irina. "Welcome to Panorama Theresienstadt. Cinematography and Destruction in the Town Called 'As If' (Reading H. G. Adler)." Edited by Natascha Drubek. Apparatus Journal, no. 2-3 (2016). https://doi.org/http://dx.doi.org/10.17892/app.2016.0002-3.48.

Sieminski, Inga, Ouida Maedel, Victoria Mattiuzzo, and Ezree Mualem. The Theresienstadt Ghetto: A Study Guide. American University \& La Salle. 2009. https://studentaffairs.lasalle.edu/butterflyproject/files/2012/12/Terezin-studyguide.pdf.

Sklar, Courtney. "Wiener Holocaust Library Blog — Wiener Library." Wiener Library. February 28, 2018. https://www.wienerlibrary.co.uk/Blog?item=297\&returnoffset=60.

Stargardt, Nicholas. "Children's Art of the Holocaust," Past \& Present 161, no. 1 (1998): 191-235. https://doi.org/10.1093/past/161.1.191.

Terezin.org. "The History of Terezin." Terezin - Children of the Holocaust. 2014. http://www.terezin.org/thehistory-of-terezin.

“Theresienstadt.” Yad Vashem. 2020. https://www.yadvashem.org/holocaust/about/ghettos/theresienstadt.html.

Troller, Norbert, Joel Shatzky, Richard Ives, and Doris Rauch. Theresienstadt: Hitler's Gift to the Jews. Chapel Hill: University Of North Carolina Press, 2004. 
Troy, Gil. “Red Cross Inspected One Concentration Camp.” The New York Times, May 29, 1987.

United States Holocaust Memorial Council. Days of Remembrance, April 3-10, 1994: Fifty Years Ago, Darkness Before Dawn. Washington DC: United States Holocaust Memorial Museum, 1994.

United States Holocaust Memorial Museum, Washington, DC. "Final Solution: Overview." United States Holocaust Memorial Museum. Last modified December 8, 2006. https://encyclopedia.ushmm.org/content/en/article/finalsolution-overview.

United States Holocaust Memorial Museum, Washington, DC. "Online Exhibition: Special Focus Theresienstadt." United States Holocaust Memorial Museum, 2019. https://www.ushmm.org/information/exhibitions/onlineexhibitions/special-focus/theresienstadt.

United States Holocaust Memorial Museum, Washington, DC. "Theresienstadt: Red Cross Visit." United States Holocaust Memorial Museum Encyclopedia. Accessed June 14, 2020. https://encyclopedia.ushmm.org/content/en/article/theresienstadt-red-cross-visit.

Wallach, Kurt. Man's Inhumanity To Man. Lulu Press, 2020.

Web.archive.org. "Verzeichnis Der Konzentrationslager Und Ihrer Außenkommandos Gemäß § 42 Abs. 2 BEG” [List of Concentration Camps and Their External Commands in Accordance with $\S 42$ (2) BEG]. 1967. https://web.archive.org/web/20121103180512/http://www.gesetze-im-internet.de/begdv 6/anlage 6.html.

Wendland, Jörn. Das Lager von Bild Zu Bild : Narrative Bildserien von Häftlingen Aus NS-Zwangslagern [The Camps from Picture to Picture: Narrative Series of Images of Prisoners from Nazi Camps]. Köln: Böhlau Verlag, 2017.

Weniger, Kay. Das Große Personenlexikon des Films [The Film's Great Encyclopedia of People] Berlin: Schwarzkopf \& Schwarzkopf, 2001.

White, Matthew. "Twentieth Century Atlas - Death Tolls." Necrometrics. 2009. http://necrometrics.com/20c5m.htm\#Second.

Woolford, Andrew. "The Führer Gives the Jews a Town: Impression Management, Homo Dramaticus, and Bare Life in Theresienstadt." Crime, Media, Culture: An International Journal 6, no. 1 (2010): 87-104. https://doi.org/10.1177/1741659010363043.

Wrasse, Marc."Deutsches Historisches Museum: Artists \& Works." Deutsches Historisches Museum. n. d. https://www.dhm.de/en/ausstellungen/archive/2016/art-from-the-holocaust/artists-works.html.

Yin, Robert K. Case Study Research: Design and Methods. Los Angeles: Sage Publications, 2009. 